\title{
Studies on food preferences of maize weevil, Sitophilus zeamais Mots. to different crops in Chitwan, Nepal
}

\author{
${ }^{1}$ Sheela Devi Sharma ${ }^{*},{ }^{2}$ Resham Bahadur Thapa, ${ }^{3}$ Gopal Bahadur KC, \\ ${ }^{1}$ Ghanashyam Bhandari and ${ }^{2}$ Sundar Tiwari \\ ${ }^{1}$ National Maize Research Program, Rampur, Chitwan \\ ${ }^{2}$ Agriculture and Forestry University, Rampur, Chitwan \\ ${ }^{3}$ Tribhubhan University, IAAS, Rampur, Chitwan, Nepal \\ *Corresponding author email: newento2014@gmail.com
}

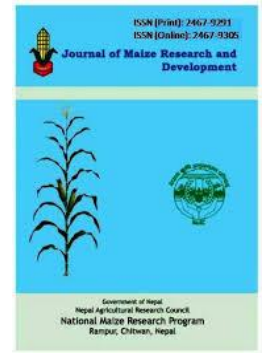

Received: September 2016; Revised: October 2016; Accepted: November 2016

\begin{abstract}
Food preference by the maize weevil, Sitophilus zeamais Motschulsky was studied on seven different crops and varieties including maize, wheat and rice. They were maize cultivars namely Arun-2, Manakamana-4, Deuti, buckwheat local cultivar, wheat cultivar namely Annapurna-1, polished rice-Radha 4 and unshelled rice cultivar Mansuli under storage condition at Institute of Agriculture and Animal Science, Rampur, Chitwan, Nepal from June 2013 to February 2014 . The hosts were tested using completely randomized design with three replications and were laid in free-choice and no-choice conditions. The maximum number of grain loss was recorded in wheat followed by polished rice respectively. Similarly, the highest weight loss was recorded in polished rice followed by Wheat in both conditions. F1 progeny emergence of weevil was highest in wheat followed by polished rice in free-choice and in no choice conditions, the highest progeny were emerged from polished rice followed by wheat. The lowest numbers of weevils emerged from rice in both conditions. Maximum germination losses were recorded in wheat (24.33\%) and lowest in Arun-2 (9.67). The rice showed a relatively higher preference to maize weevil under storage condition.
\end{abstract}

Keywords: Food, maize, preference, weevil

Correct citation: Sharma, S., Thapa, R.B., KC, G.B., Bhandari, G., \& Tiwari, S. (2016). Studies on food preferences of maize weevil, Sitophilus zeamais Mots. to different crops in Chitwan, Nepal. Journal of Maize Research and Development, 2 (1): 58-65,

doi: http://dx.doi.org/10.3126/jmrd.v2i1.16215

\section{INTRODUCTION}

Maize is the second most important staple food crop both in terms of area and production after rice in Nepal. It was grown in 0.87 million hectare of land with an average yield of 2.09 t/ha. Maize occupied about $28.32 \%$ of the total cultivated agricultural land and shares about $23.89 \%$ of the total cereal production in Nepal (MoAC, 2010). In stored maize, heavy infestation of weevil cause weight losses of with ranges from 30-40\% (Paneru et al., 1996). Maize weevil is one of the most serious, internal feeding pests of maize seed and grain. $S$. zeamais is found in all tropical and sub-tropical parts of the world (Dobie, 1974). Maize 
weevil can infest various stored agricultural products such as maize, sorghum, wheat, barley, rice and paddy (rough rice). There was no exact information on the quantification of post-harvest losses; however estimated loss ranged 5-40\% (Manandhar et al., 2004). The damage and losses caused by these factors have been estimated $2-30 \%$ by weight basis (Entomology Division, 1999).Among these factors insect has been considered as the major part for the reduction of the quality and quantity of the maize. Paneru et al.(1996) reported storage losses due to weevil up to $31 \%$ by weight basis on maize. In Nepal, since past time, a great concern has been given to the crop growing practices for the enhancement of the production and productivity. Most of the researches had been focused on field practices like cultivation practices, insect pest management, and disease management and so on. But still, the post-harvest problems including storage insect problems, has been given less priority. In this regards, the host preference study were conducted to get the information of pest on stored products. In Nepal, farmers don't have a separate storage room for different crops and most of the farmers stored maize along with other crops like wheat, rice and buckwheat etc. Hence, weevil might get suitable environment for breeding or food in other crops. In such situation, the study will give the information that storage product should be stored separately and should prevent to contact from one host to another host to reduce its population build up.

\section{MATERIALS AND METHODS}

The experiment was conducted at Institute of Agriculture and Animal Sciences (IAAS) Rampur, Chitwan. The following grains were collected from the farmers household and research institutions. Three major maize cultivars and four other common stored grains i.e. Maize cv. Arun-2, maize cv. Manakamana-4, maize cv. Deuti, buckwheat cv. local, wheat cv. Annapurna-1, polished rice cv Radha 4 and unshelled rice cv, Mansuli were used for the experiment. Fifty grams of each treatments were kept in the free-choice and no-choice containers and were replicated thrice. The grains were kept in the Petri plates and were arranged in circular fashion in a circular plastic bucket. Similarly, weevils were confined in no-choice conditions in separate containers.

\section{Free-choice condition}

Forty newly emerged weevils were released in the center of the chamber. The whole set of experiments were covered by mosquito nets to prevent the escape of weevils. Adult weevils were removed after seven days for maximum oviposition as standard length of time (Dobie, 1974). The experiment was laid out into Complete Randomized Design (CRD) with three replications.

\section{No- choice condition}

The relative preference of different hosts by $S$. zeamais was also studied under no choice condition in Rampur, Chitwan and design was Completely Randomized Design (CRD). Treatments and the method of seed preparation were same as mentioned in free choice condition. Fifty grams of seeds were taken in a plastic jar of half kg capacity. In order to proper aeration, the mouth of the jar was covered with net with the help of rubber bands. The newly emerged ten weevil individuals were released in each container. 


\section{Data recording and Analysis}

The adults were removed after seven days and further data were recorded after 10 days of weevil removal. Subsequent data were recorded at 20 days interval and continued for the period of 2 months. The following parameters were recorded for both varietal screening and host preference.

- Germination percent before experimental setup and at end of experiment of each treatment

- Number of damaged / undamaged grains

- Weight of damaged / undamaged grains

- Moisture percentage of grains

- Number of $F_{1}$ progeny emergence

- Room temperature and R. H.

All the grains were counted and weighted for calculating the weight loss and number of grain damage in each data recording time. The percent weight loss and percent grain damage was calculated thereafter. All data were analyzed statistically using MSTAT-C and MS-Excel.

\section{RESULTS AND DISCUSSION}

\section{Host preferences under free-choice condition}

\section{Grain damage percentage}

The grain damage percentage by weevil in different possible hosts of weevil were significantly different $(\mathrm{P}<0.01)$ in each other over the observation period (Table 1$)$. Wheat was the most preferred maize variety by weevil during different observation periods, whereas paddy was the least preferred host of weevil. Ranson (2000) suggested that soft types of grains are more suitable for weevil damage than hard nature of crop seeds. In 20 days of observation, polished rice was found to be statistically superior and most susceptible to weevil and loss recorded about 6 percent whereas, the least damage percentage was recorded in Deuti variety of maize $(1.06 \pm 0.46)$. The other hosts, buckwheat, Arun-2, and Manakamana-4 were not significantly different in terms of loss caused by weevil (Table 1).

Table 1. Percent grain damage by Maize weevil, $S$. zeamais under free-choice condition at Rampur, Chitwan, Nepal, 2013.

\begin{tabular}{lccc}
\hline \multirow{2}{*}{ Hosts } & \multicolumn{3}{c}{ Percent Grain Damage (No. basis) at indicated days after treatment } \\
\cline { 2 - 4 } & 20 day & 40 day & 60 day \\
\hline Arun-2 & $1.84^{\mathrm{bc}} \pm 0.89$ & $4.17^{\mathrm{b}} \pm 0.33$ & $20.73^{\mathrm{b}} \pm 2.75$ \\
Manakamana-4 & $1.57^{\mathrm{bc}} \pm 1.09$ & $8.14^{\mathrm{b}} \pm 0.24$ & $20.19^{\mathrm{b}} \pm 2.89$ \\
Deuti & $1.06^{\mathrm{c}} \pm 0.46$ & $7.41^{\mathrm{b}} \pm 1.30$ & $17.69^{\mathrm{b}} \pm 2.65$ \\
Buckwheat & $2.63^{\mathrm{bc}} \pm 1.16$ & $1.14^{\mathrm{b} \pm 1.08}$ & $4.61^{\mathrm{c}} \pm 1.13$ \\
Wheat & $2.94^{\mathrm{ab}} \pm 0.00$ & $20.60^{\mathrm{a}} \pm 8.59$ & $42.28^{\mathrm{a}} \pm 3.01$ \\
Policed Rice & $4.97^{\mathrm{a}} \pm 2.00$ & $8.64^{\mathrm{b}} \pm 3.05$ & $34.30^{\mathrm{a}} \pm 6.02$ \\
Paddy & $0.18^{\mathrm{c}} \pm 0.00$ & $0.15^{\mathrm{b}} \pm 0.02$ & $0.10^{\mathrm{c}} \pm 0.12$ \\
\hline PValue & $<0.01$ & $<0.01$ & $<0.01$ \\
CV \% & 22.09 & 10.79 & 11.33 \\
LSD $_{0.05}$ & 1.525 & 8.53 & 10.07 \\
\hline
\end{tabular}

Similarly, in 40 days of observation, the maximum losses were recorded in wheat 
(20.60 \pm 8.59 ), which was significantly different from other hosts. The rest other hosts were not statistically different. Rice was the least preferred host of weevil. Singh (2002) reported susceptibility of weevil negatively co-related with grain hardness and crude fiber content which lead to reduce the damage to paddy. In 60 days of observations, the treatments were significant among each other $(\mathrm{P}<0.01)$. The two host's wheat $(42.28 \pm 3.01)$ and polished rice (34.30 \pm 6.02$)$ based on damage percent were at par. The paddy and buckwheat were less susceptible hosts in comparison to the other hosts of weevil.

The percent grain infestation by weevil in free choice condition over the observation period were highly significant from each other's (Table 2). The increasing trends of damage percentage were recorded over the observation periods. In 20 days, the maximum grain weight loss was recorded in polished rice which was significantly higher to the other hosts $(\mathrm{P}<0.01)$. The other hosts were at par with each other. In 40 days of observation, the similar trend of infestation was recorded. The highest damage percentage was recorded in polished rice $(7.53 \pm 0.23)$ followed by wheat $(5.73 \pm 1.45)$. The highest loss was recorded in polished rice $(21.33 \pm 0.85)$ followed by wheat $(10.13 \pm 1.16)$ whereas minimum loss was recorded in rice which was not significantly different with other hosts like Arun-2, Manakamana-4, Deuti and buckwheat. About $15 \%$ of the grains are lost in storage by the pests (Joshi, Karmacharya \& Khadge, 1991) which is almost same with the result below. Among the maize verities, maximum damage was recorded in Deuti in comparison to other two maize varieties which could be associated with the starch content and size of kernel (Golob, 1984). Similarly, yellow varieties of maize are more susceptible by weevil damage than other color varieties of crops (NMRP, 2011/2012).

Table 2. Percent grain damage by Maize weevil, $S$. zeamais under free-choice condition at Rampur, Chitwan, Nepal, 2013.

\begin{tabular}{lccc}
\hline \multirow{2}{*}{ Hosts } & \multicolumn{3}{c}{ Percent Grain Damage (Wt. basis) at indicated days after treatment } \\
\cline { 2 - 4 } & 20 day & 40 day & 60 day \\
\hline Arun-2 & $0.80^{\mathrm{b}} \pm 0.35$ & $3.33^{\mathrm{c}} \pm 1.42$ & $3.67^{\mathrm{c}} \pm 1.20$ \\
Manakamana-4 & $0.70^{\mathrm{b}} \pm 0.72$ & $2.80^{\mathrm{c}} \pm 0.69$ & $2.00^{\mathrm{c}} \pm 0.43$ \\
Deuti & $1.00^{\mathrm{b}} \pm 1.11$ & $2.00^{\mathrm{c}} \pm 1.06$ & $3.33^{\mathrm{c}} \pm 0.75$ \\
Buckwheat & $1.53^{\mathrm{b}} \pm 0.95$ & $4.13^{\mathrm{c}} \pm 1.17$ & $3.20^{\mathrm{c}} \pm 1.21$ \\
Wheat & $2.06^{\mathrm{b}} \pm 0.58$ & $5.73^{\mathrm{b}} \pm 1.45$ & $10.13^{\mathrm{b}} \pm 1.16$ \\
Policed Rice & $9.67^{\mathrm{a}} \pm 0.61$ & $7.53^{\mathrm{a}} \pm 0.23$ & $21.33^{\mathrm{a}} \pm 0.85$ \\
Paddy & $2.00^{\mathrm{b}} \pm 0.20$ & $2.07^{\mathrm{c}} \pm 0.64$ & $2.60^{\mathrm{c}} \pm 0.53$ \\
\hline P Value & $<0.01$ & $<0.01$ & $<0.01$ \\
CV \% & 11.63 & 12.02 & 13.67 \\
LSD $_{0.05}$ & 1.24 & 1.53 & 2.49 \\
\hline
\end{tabular}

\section{F1 progeny of weevil on different hosts}

The level of significance among the treatments in three observations period were varied (Table 3). In 20 days interval, the weevil population among the treatments were significantly different. In 20 days, the highest weevil population was recorded in polished rice $\left(42.66^{\mathrm{b}} \pm 15.43\right)$ which was significantly different from other hosts and lowest number of weevil population was recorded in paddy $\left(2.66^{\mathrm{a}} \pm 2.51\right)$ which was not significantly different with other host than polished rice. The similar result was also reported by Throne and Eubanks (2002) and who explained that the hard surface of paddy deterred the oviposition and thus lowered the weevil population. 
In 60 days of observation, the maximum numbers of weevil population were counted in wheat $(192.33 \pm 8.52)$ and polished rice $(116.33 \pm 4.59)$ which was statistically different each other. The polished rice was the second most preferred host in terms of population buildup. Similarly, the other hosts, Arun-2 and Manakamana-4, and Deuti and Buckwheat were similar to each other. Entomology Division (2001) found that adults of S. zeamais developed the progeny very easily on the host with soft outer cover which absorbs the moisture easily and this result is on the same line. In general, weevil multiplication, and their damage depends on many factors such as temperature, moisture content of grains, hardness and softness of grain endosperm and quality of the grain (Entomology Division, 2011/2012) (Table 3).

Table 3. Population buildup of $S$. zeamais on different hosts under free-choice condition at Rampur, Chitwan, Nepal, 2013.

\begin{tabular}{lccc}
\hline \multirow{2}{*}{ Hosts } & \multicolumn{3}{c}{ Weevil Population (No.) at indicated days after treatment } \\
\cline { 2 - 4 } & 20 day & 40 day & 60 day \\
\hline Arun-2 & $14.33^{\mathrm{a}} \pm 6.56$ & $23.67^{\mathrm{abc}} \pm 12.35$ & $60.33^{\mathrm{bc}} \pm 15.15$ \\
Manakamana-4 & $14.27^{\mathrm{a}} \pm 5.47$ & $24.00^{\mathrm{abc}} \pm 8.00$ & $50.00^{\mathrm{bc}} \pm 13.00$ \\
Deuti & $7.00^{\mathrm{a}} \pm 3.10$ & $21.33^{\mathrm{bc}} \pm 8.37$ & $30.66^{\mathrm{c}} \pm 9.29$ \\
Buckwheat & $11.00^{\mathrm{a}} \pm 0.10$ & $23.00^{\mathrm{bc}} \pm 4.30$ & $30.66^{\mathrm{c}} \pm 9.68$ \\
Wheat & $12.33^{\mathrm{a}} \pm 2.08$ & $58.33^{\mathrm{a}} \pm 30.22$ & $192.33^{\mathrm{a}} \pm 8.52$ \\
Polished Rice & $42.66^{\mathrm{b}} \pm 15.43$ & $41.00^{\mathrm{ab}} \pm 34.84$ & $116.33^{\mathrm{b}} \pm 4.59$ \\
Paddy & $2.66^{\mathrm{a}} \pm 2.51$ & $7.00^{\mathrm{c}} \pm 2.45$ & $11.67^{\mathrm{c}} \pm 2.31$ \\
\hline P Value & $<0.05$ & $<0.05$ & $<0.01$ \\
CV \% & 23.95 & 10.48 & 24.28 \\
LSD $_{0.05}$ & 12.16 & 47.99 & 40.86 \\
\hline
\end{tabular}

\section{Host preferences under no-choice condition}

\section{Grain damage percentage}

The grain damage percentage were highly significant $(\mathrm{P}<0.01)$ in different days of observations (Table 4). In 20 days of observation, maximum infestation was recorded in polished rice $(7.30 \pm 1.114)$ followed by wheat $(3.28 \pm 1.14)$, buckwheat $(1.96 \pm 0.00)$, Deuti (1.59 \pm 0.00$)$, Manakamana-4 (1.18 \pm 0.83$)$, Arun-2 $(0.97 \pm 0.33)$ and lowest loss recorded in rice $(0.053 \pm 0.02)$. Arun- 2 and Manakamana-4 were at par. Similarly, damage percentage of wheat loss was recorded highest $(37.29 \pm 17.53)$ in 40 days of observation which was statistically different from the tested hosts. Lowest damage percentage was recorded in rice $(0.72 \pm 1.11)$. The percentage loss of some hosts like Manakamana-4 $(9.42 \%)$, Deuti $(8.73 \%)$, Arun-2 $(5.03 \%)$, buckwheat $(1.33 \%)$ and rice $(0.72 \%)$ were not statistically different. Physical characteristics, i.e. seed hardness might have reduced the amount of feeding (Bernabe-Adalla, 1976) and reduce the infestations.

In 60 days of observation, the treatments were also highly significant $(\mathrm{P}<0.01)$. Grain loss was recorded highest in wheat (71.29 \pm 8.12$)$, which was significantly different from other tested hosts. Polished rice was the second most susceptible hosts of weevil, with recorded upto $47.00 \%$. The lowest percentage loss was recorded in paddy which accounts only $0.12 \%$. The other hosts like Arun-2, Manakamana-4, Deuti were not significantly different from each other in terms of grain loss. 
Table 4. Mean percent infestation of $S$. zeamais in different food under no- choice experiment in Chitwan, condition during 2013.

\begin{tabular}{lccc}
\hline \multirow{2}{*}{ Hosts } & \multicolumn{3}{c}{ Percent Grain Damage (No. basis) at indicated days after treatment } \\
\cline { 2 - 4 } & 20 day & 40 day & 60 day \\
\hline Arun-2 & $0.97^{\mathrm{cd}} \pm 0.33$ & $5.03^{\mathrm{b}} \pm 0.89$ & $17.44^{\mathrm{c}} \pm 3.81$ \\
Manakamana-4 & $1.18^{\mathrm{cd}} \pm 0.83$ & $9.42^{\mathrm{b}} \pm 4.23$ & $28.09^{\mathrm{c}} \pm 6.16$ \\
Deuti & $1.59^{\mathrm{bcd}} \pm 0.00$ & $8.73^{\mathrm{b}} \pm 1.38$ & $23.01^{\mathrm{c}} \pm 3.64$ \\
Buckwheat & $1.96^{\mathrm{bc}} \pm 0.00$ & $1.33^{\mathrm{b}} \pm 0.08$ & $2.04^{\mathrm{d}} \pm 1.83$ \\
Wheat & $3.28^{\mathrm{b}} \pm 1.14$ & $37.29^{\mathrm{a}} \pm 17.53$ & $71.29^{\mathrm{a}} \pm 8.12$ \\
Policed Rice & $7.30^{\mathrm{a} \pm 1.14}$ & $27.32^{\mathrm{ab}} \pm 4.77$ & $47.31^{\mathrm{b}} \pm 5.03$ \\
Paddy & $0.053^{\mathrm{d}} \pm 0.02$ & $0.72^{\mathrm{b}} \pm 1.11$ & $0.12^{\mathrm{d}} \pm 0.07$ \\
\hline PValue & $<0.01$ & $<0.01$ & $<0.01$ \\
CV \% & 29.83 & 34.24 & 17.70 \\
LSD $_{0.05}$ & 1.693 & 26.61 & 11.63 \\
\hline
\end{tabular}

Table 5 showed that the grain damage percent in weight basis were highly significant ( $\mathrm{P}<0.01)$. In general, polished rice and wheat were highly preferred hosts of weevil. In 20 days of treatment set up, the weight loss of polished rice was found to be maximum $(10.33 \pm 0.70)$, which was significantly different with other tested hosts. The other tested hosts were at par in terms of infestation. In 40 days, the same results were observed as in 20 days of observations. In general, maximum loss was recorded in polished rice (9.20 \pm 0.92$)$ followed by wheat $(4.33 \pm 1.10)$, and lowest loss was recorded in rice $(0.66 \pm 0.23)$. Classen et al. (1990) reported that pericarp hardness has been associated with resistance to maize weevil. Similarly, in 60 days of observation: highest loss was recorded in polished rice $(11.46 \pm 0.42)$ and lowest in paddy $(1.67 \pm 0.12)$.

Table 5. Mean percent infestation of $S$. zeamais in different food under no- choice experiment in Chitwan, condition during 2013.

\begin{tabular}{lccc}
\hline \multirow{2}{*}{ Hosts } & \multicolumn{3}{c}{ Percent Grain Damage (Wt. basis) at indicated days after treatment } \\
\cline { 2 - 4 } & 20 day & 40 day & 60 day \\
\hline Arun-2 & $1.33^{\mathrm{b}} \pm 0.42$ & $2.06^{\mathrm{bc}} \pm 0.50$ & $3.33^{\mathrm{c}} \pm 0.50$ \\
Manakamana-4 & $2.00^{\mathrm{b}} \pm 0.72$ & $3.33^{\mathrm{b}} \pm 0.92$ & $2.60^{\mathrm{cd}} \pm 0.40$ \\
Deuti & $1.60^{\mathrm{b}} \pm 1.00$ & $2.66^{\mathrm{bc}} \pm 0.90$ & $3.13^{\mathrm{c}} \pm 0.58$ \\
Buckwheat & $1.93^{\mathrm{b}} \pm 0.64$ & $2.66^{\mathrm{bc}} \pm 1.17$ & $3.00^{\mathrm{cd}} \pm 0.53$ \\
Wheat & $2.86^{\mathrm{b}} \pm 0.50$ & $4.33^{\mathrm{b}} \pm 1.10$ & $8.66^{\mathrm{b}} \pm 0.90$ \\
Policed Rice & $10.33^{\mathrm{a}} \pm 0.70$ & $9.20^{\mathrm{a}} \pm 0.92$ & $11.46^{\mathrm{a}} \pm 0.42$ \\
Paddy & $1.06^{\mathrm{b}} \pm 1.15$ & $0.66^{\mathrm{c}} \pm 0.23$ & $1.67^{\mathrm{d}} \pm 0.12$ \\
\hline PValue & $<0.01$ & $<0.01$ & $<0.01$ \\
CV \% & 25.62 & 24.66 & 11.12 \\
LSD $_{0.05}$ & 1.88 & 2.13 & 1.31 \\
\hline
\end{tabular}

\section{Germination loss}

The actual loss percent of different treatments were significantly different to each other $(\mathrm{P}<0.05)$. Maximum germination loss was recorded in wheat $(24.33 \pm 4.04)$ followed by polished rice, Deuti (16.33 \pm 1.53$)$, rice (14.00 \pm 9.54$)$, Manakamana-4 (12.33 \pm 2.52$)$ and lowest in Arun-2 (9.67 \pm 3.51$)$ (Table, 6). The germination on polished rice was not recorded because of all seeds were damaged by weevil. With the increase in insect infestation, the tendency in the decrease in germination of the seeds occur (Prakash et al., 1987), which is in accordance of the given table. Similarly, Panthee (1977) reported that higher germination loss was related 
with higher weevil activities.

Table 6. Reduction in germination in different host of Maize weevil, $S$. zeamais at Rampur, Chitwan, Nepal, during 2013

\begin{tabular}{lccc}
\hline & & Germination $(\%)$ \\
\cline { 2 - 4 } Treatments & Before treatment & After treatment & $\begin{array}{c}\text { Actual germination } \\
\text { loss }\end{array}$ \\
\hline Arun-2 & $86.33^{\mathrm{b}} \pm 1.53$ & $76.67^{\mathrm{a}} \pm 2.89$ & $9.67^{\mathrm{c}} \pm 3.51$ \\
Manakamana-4 & $85.67^{\mathrm{b}} \pm 1.15$ & $73.33^{\mathrm{a}} \pm 2.89$ & $12.33^{\mathrm{bc}} \pm 2.52$ \\
Deuti & $96.33^{\mathrm{a}} \pm 1.53$ & $80.00^{\mathrm{a}} \pm 0.00$ & $16.33^{\mathrm{abc}} \pm 1.53$ \\
Buckwheat & $74.67^{\mathrm{c}} \pm 2.52$ & $60.00^{\mathrm{bc}} \pm 5.00$ & $14.67^{\mathrm{bc}} \pm 4.62$ \\
Wheat & $82.67^{\mathrm{b}} \pm 2.52$ & $58.33^{\mathrm{c}} \pm 2.89$ & $24.33^{\mathrm{a}} \pm 4.04$ \\
Paddy & $97.33^{\mathrm{a}} \pm 2.08$ & $83.33^{\mathrm{a}} \pm 10.41$ & $14.00^{\mathrm{bc}} \pm 9.54$ \\
\hline P Value & $<0.01$ & $<0.01$ & $<0.05$ \\
CV \% & 2.33 & 6.83 & 31.66 \\
LSD $_{0.05}$ & 4.97 & 11.93 & 8.89 \\
\hline
\end{tabular}

\section{CONCLUSION}

Wheat and polished rice were most preferred host and loss recorded up to $42.00 \%$ on number basis. Whereas, rice and buckwheat were the least preferred host of weevil. Highest numbers of weevils were emerged in wheat and polished rice whereas least number of progenies were released from rice. Maximum germination losses were recorded in wheat and lowest germination loss was recorded in Arun-2. Therefore this study suggested that rice and buckwheat are relatively less preferred to maize weevil and they can be stored for long time. In summary, the research give idea about proximity of storage for storage crops during stored inside the house. If we stored other more susceptible maize cultivars and other non-maize foods together, the weevil might get the suitable environment for population build up.

\section{ACKNOWLEDGEMENTS}

Tribhuvan University, Entomology Laboratory and University Grant Commission are highly acknowledged for providing the research space and financial supports respectively.

\section{REFERENCES}

Bernabe-Adalla, C., \& Bernado, E. N. (1976). Correlation between husk characters and weevil infestation of 51 varieties and lines of maize in the field. Philippine Agricultural Science, 60, 121-129.

Champ, B. R., \& Dyte, C. E. (1977). FAO global survey of pesticide susceptibility of stored grain pests. FAO Plant Protecion Bulletin 25(2), 49-67.

Classen, D. Arnason, J.T., Serratos, J.A., Lambert, J.D.H., Nozzolillo, C., \& Philogeneet al, B.J.R. (1990). Correlation of phenolic acid content of maize to resistance to Sitophilus zeamais, the maize weevil, in CIMMYT'S collections. Journal of Chemical Ecology. 16 (2), 301-315.

Dobie, P. (1974). The laboratory assessment of the inherent susceptibility of maize varieties to post harvest infestations by Sitophilus zeamais Mots. Journal of Stored Product Research, 10, 183-197.

Dobie, P. (1977). The contribution of the tropical stored products center to the study of the 
insect resistance in stored maize. Tropical Stored Products Information, 34, 7-22.

Entomology Division. (2001). Annual Technical Report of 1999/2000. Entomology Division, Nepal Agricultural Research Council, Khumaltar, Nepal. pp.20-24.

Golob, P. (1984). Improvements in maize storage for the small holder farmer. Tropical Stored Products Information ,50, 14-19.

Gomez, K. A., \& Gomez, A. A. (1986). Statistical Procedures for Agricultural Research. $2^{\text {nd }}$ edition. John Wiley \& Sons, inc. New York, USA.

Joshi, S.L., Karmacharya, B.B., \& Khadge, B.R.. (1991). Trainers manual no. 14. Plant Protection. Manpower Development Agriculture Project, Kathmandu, November, 1991. pp.397.

Khare, B. P. (1994). Stored grain pest and their management. Kalyani Publishers, Ludhiyana, India. pp.314.

Manandhar, R., Sharma, P. N., \& Devkota, S.R. (2004). Loss assessment of maize grains due to storage pest under different storage conditions in different Agro-ecological environments. In:Sherchan, D.P., Adhikari, K ,Basta, B.K.\& Sharma, D. (eds.). Summer Crops Research Workshop on Maize Research and Production in Nepal. Kathmandu, Nepal, June 28-30, 2004. Proceedings of the $24^{\text {th }}$ National Summer Crops on Maize Research and Production in Nepal. NMRP, NARC. pp. 241-243.

MoAC. (2010). Statistical information on Nepalese agriculture. Government of Nepal. Ministry of Agriculture and Cooperatives, Agri-Business Promotion and Statistics Division, Singh Darbar, Kathmandu, Nepal.

NMRP. (2011/2012). 2011/2012 Annual Report of National Maize Research Program (NMRP), Rampur Chitwan, Nepal 172p.

Paneru, R.B., Duwadi, V.R., Khanal, R., \& Bhattarai, M.R. (1996). Testing of the efficacy of some local materials against weevil in stored maize. Rep. No. 139. PAC, Dhankuta.

Panthee, D. R. (1997). Identification of a suitable indigenous storage structure for Wheat seed storage. Journal of Agriculture and Animal Science, 17(18),55-62.

Prakash, A., Rao, J., Pasalu, I. C., \& Mathur, K. C. (1987). Rice storage and insect pest management. B. R. Publishing Corporation, Delhi. pp. 321.

Ransom, J. (2000). Factors affecting post harvest losses in maize. In:Manandhar, D. N, Ransom, J. K. Ransom \& Rajbhandari, N.P. (eds.). Working Group Meeting of the Hill Maize Research Project. Khumaltar, Nepal, September 25-27, 2000. Developing and Dissemination Technology to Reduce Post-harvest Losses in Maize Proceedings. CIMMYT/NARC. pp. 14-18.

Singh, C. (2002). Modern techniques of raising field crops. Oxford and IBH Publishing Co. Pvt. Ltd., New Delhi, India. pp.573.

Throne, J.E., \& Eubanks, M.W. (2002). Resistance of Tripsacorn to Sitophilus zeamais and Oryzae philussurinamensis. Journal of stored product research, 38 (2), 239-245. 